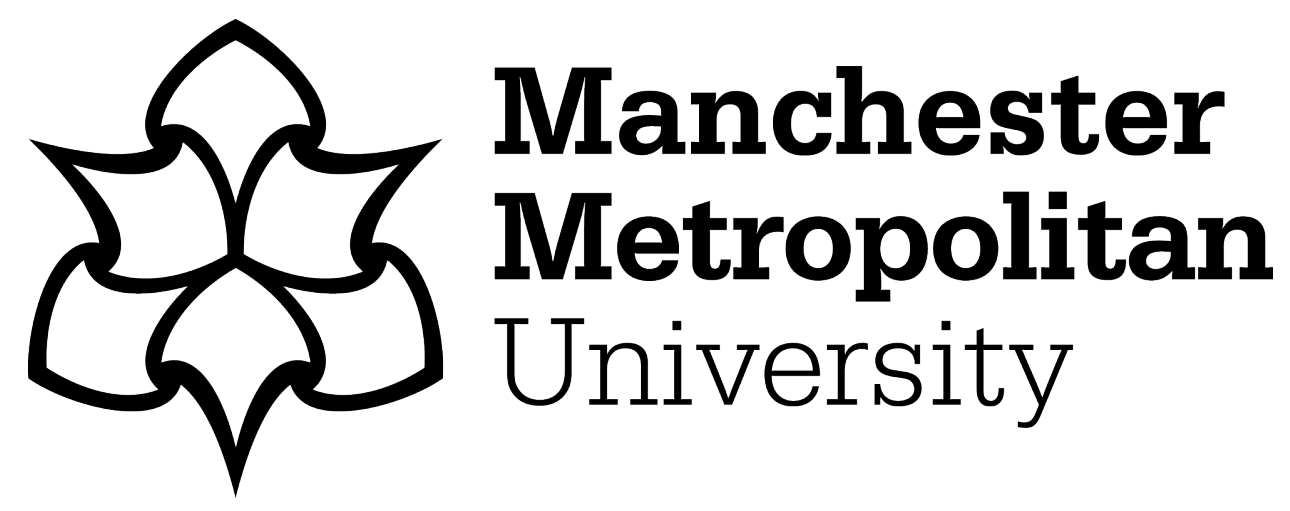

Warstat, Andrew (2018) Adorno, Lewis Klahr and the Shuddering Image. In: Drawn from Life: Issues and Themes in Animated Documentary Cinema. Edinburgh University Press. ISBN 0748694110

Downloaded from: https://e-space.mmu.ac.uk/618560/

Publisher: Edinburgh University Press

Please cite the published version 


\title{
Adorno, Lewis Klahr and the Shuddering Image
}

\author{
Andrew Warstat
}

The work of animator and filmmaker Lewis Klahr is barely recognisable as documentary. His works are fragmented, surreal, stop-frame investigations hard to categorise alongside contemporary films routinely referred to as examples of animated documentary, work such as Waltz with Bashir (Ari Folman, 2008) or Persepolis (Vincent Paronnaud and Marjane Satrapi, 2007) (see, for example, Honess Roe 2013: 139-69). Klahr makes no direct attempt to engage with common-sense, conventional definitions of 'reality' through naturalistic forms of cinematic representation or storytelling. To see Klahr's films as documentary, one has to look beyond a straightforward definition of that concept. Making such an interpretative leap, however, allows for an examination of how animation itself can be understood as a visual medium that is entangled in history and politics, and that thus contains individual works that can be plausibly understood as 'documents' in certain ways.

This essay uses consideration of Klahr's work as a vehicle through which a range of questions closely related to the idea of 'animated documentary' can be explored. Is there an opposition between the documentary and the document? What are some of the ways in which the 'documentary turn'1 in filmmaking and art practice during the last two decades might be symptomatic of contemporaneous concerns with the relationship between the factual, the social and the cultural? Is a distinction between concepts of the documentary and the document helpful when we come to consider a specific emergent filmmaking tradition such as documentary animation? And, does that attempted distinction relate to the traditional binary opposition between form and content visible within countless critical discussions and creative works drawn from a variety of aesthetic traditions, documentary film and animation included?

Recent critical suggestions that there is indeed such a genre of film as animated documentary perhaps have their roots in a conviction that it is possible to identify a more or less coherent form of film object which can be associated with that generic label (see, for example, Glynne 2013; Honess Roe 2013). An animated documentary might (or might not) address certain forms of subject 
matter; it might (or might not) be a film work that is constructed according to certain consensually recognised and respected narrative conventions; it might (or might not) conform to certain similarly agreed rules about how to represent particular real-life events or issues. But to study this supposed cinematic genre as a symptom of something broader, or as a documentary form (and/ or repository) in and of itself, would also be to consider notable scale of the so-called documentary turn in recent cultural production (including animation). Recent shifts in cinematic forms and genres, together with alterations in the content addressed by those forms, suggest broader movements within contemporary society: a certain set of artistic and cultural forms links to a certain set of cultural and historical issues.

One central question within such an exploration relates, therefore, to how cultural texts (such as films) are, arguably, subject to a two-stage encoding process. Such texts' ostensible narrative and aesthetic content is supplemented by another order of content altogether. The latter is associated with historical events and processes of change witnessed and experienced within the wider world. Every film is simultaneously 'about' something while also implying something else beyond the text itself. In Theodor Adorno's terms, this problem with form and content indicates how artistic forms are always encrusted with, or enmeshed in, history. This is so regardless of any given artwork's struggle to describe, show, or even escape from the very history that informs and enfolds it. Such a formulation of the concept of 'the document' seems implicit in Adorno's claim (1997: 5) in Aesthetic Theory that every artistic form contains 'sedimented content'. Questions of form - and why a form is used or occurs at one historical moment rather than another - can only be answered, Adorno argues, through an analysis of how a specific form relates or connects to the wider world. The notion of sedimented content is, therefore, the artwork or film's social life, something that is built up through viewing, re-viewing, attention and forgetting, analysis and reflection (ibid.).

Of course, the suggestion that individual films and works of art are products of a specific social context might seem no more than an unremarkable statement of the obvious, an idea now automatically accepted as par for the course within scholarly disciplines such as cultural studies and film studies. But this essay argues that what the relationship between the form and content of the document and the documentary throws into relief is how, during the past twenty years, a significant proportion of contemporary art and film production has actively attempted to develop innovative strategies to engage with a diverse range of social and political issues. More specifically, it is possible to identify the reason why the documentary form has recently assumed such prominence within a range of different creative media. It is only by considering this question - in other words, by considering the documentary as itself a 
document or evidence of something - that one can begin to understand the reasons why, and ways in which, animated documentaries are contemporarily significant.

Brief consideration of this overarching contemporary critical and cultural context brings us to the work of Lewis Klahr. Klahr has been making cutand-paste, stop-frame animated films since the late 1970s. Although originally based in New York, his work has a clear visual connection to that of West Coast American animators such as Harry Smith and Larry Jordan, although Klahr's work may also owe a debt to the 1970s Punk aesthetic of DIY cutand-paste. Klahr is known for his unsettling work with dreamlike narratives, constructed from the remnants of 1940s, '50s and '60s American mass visual culture: the magazines, adverts and flyers left over from the so-called 'golden age' of US pop culture. In the words of James Hobermann (2000), Klahr is a filmmaker who 'traffics in both psychic scars and cultural remembrance'. According to Mark McElhatten, Klahr is 'intensely archeological [sic] in his approach to autobiography and cultural ephemera ... he is a creator of atmospheres - ontological terrains where events and emotions register with archetypal power and dreamlike intensity' (Redcat 2006). In essence, imagine the world of mid-twentieth-century-set television series Mad Men (2007-15) turned into a stop-frame animation. Indeed, commenting on his 2011 film The Pettifogger, Klahr himself connects his work to the style and mood of Mad Men. He suggests that the latter channels the 'optimism felt in early-'60s American culture and the kind of modernity found in The Pettifogger' (Goddard 2012).

Reading the secondary literature on Klahr, one invariably finds the suggestion that the sequences he constructs invite the viewer to drift off into an uncanny world, one haunted with nostalgia for the recently lost past. Given that Klahr builds his films from collected archival material, it is unsurprising to find his work described as the reanimation of a disappeared world of American popular culture. Klahr calls his dense psychosocial narratives cultural autobiographies, suggesting that his films work as 'an exploration of the parts of his identity [that Klahr] has culturally inherited' (Chimovitz 1998). Moreover, if the visual material from which Klahr constructs his films is deliberately out-dated, so too are the formal techniques of filmic construction (stop-frame and cut-out animation) that he uses in order to make those works. Klahr's use of such techniques is far more crude (in purely craftbased terms) than that of, say, Lotte Reiniger's 1926 cut-out masterpiece The Adventures of Prince Achmed.

To understand how the above-noted opposition between ideas of documentary and ideas of the document can be a productive one to invoke when analysing Klahr's work, we need to look in more detail at a specific film: in this instance, the stop-frame, 1950s film noir-inflected Altair. Altair was made 
in 1994 on 16 mm film, using images culled from six late-1940s issues of Cosmopolitan magazine; it subsequently became one part of Klahr's seven-film series Engram Sepals (2000). One way of reading Altair is to understand it as the story of a female protagonist who travels through a world populated by more or less malign forces. The character is swayed by the mysterious power of money, suffers numerous forms of identity crisis, is the victim of the power of desire (both sexual and material), and falls prey to the instability of time (unable to move into the future, she regresses into the murkiness of the unresolved past). The film concludes with the character engulfed in an alcoholic daze: drifting off into a stupor, the woman is smothered by the hand of an unseen antagonist. She is trampled underfoot, the victim of uncontrollable and unpredictable forces.

Altair is peppered with references to the stars (the film's title refers to the eponymous star that is one of the closest celestial bodies visible to the naked eye); to astrology (an allusion to the process of forecasting the future, but also a reference to science fiction); and to colour symbolism and coding (blue works within this film, for example, as a cipher for transcendence or generalised notions of 'the beyond'). As Klahr comments:

The narrative is highly smudged leaving legible only the larger signposts of the female protagonist's story. The viewer is encouraged to speculate on the nature and details of the woman's battle with large, malevolent societal forces and her descent into an alcoholic swoon. However, it is important to note that all of the above was only discovered on the editing table. What motivated me during the shooting of this film, which was largely improvisatory, was a fascination with the colour blue and some ineffable association it has for me with both California and what I imagined to be the great sense of relieved openness of the post-war 1940s. (LUX n.d.)

It might be possible, therefore, to suggest that this film simply wallows in a lost past, one made safely surreal through use of fashionably retro imagery and an artfully crafted mood. Altair's ostensible content shows a fascinating, melancholic, but essentially sealed-off place to dream about a slightly sinister past.

Klahr has done nothing to dissuade viewers from thinking of Altair in this way, suggesting in interviews that his work is a Benjaminian fragment fixated on the outdated Arcade that is mid-twentieth-century American popular culture. He has noted that his filmmaking work is motivated by the urge to preserve: 'Since I was a boy I've been sensitive to what was disappearing. Once an object or image is outmoded, it is dead. So I primarily work with dead images, which makes me a reanimator, not an animator' (Pipolo 2013: 247). But this authorial suggestion that Altair is constructed from the 
archaeological remnants of a now-lost culture is of significance because it allows us to think about how Klahr's work can be read as cultural autobiography and, perhaps, as a form of animation that has a relationship to wider critical and cultural concepts of the document.

Walter Benjamin, of course, was fascinated with how the detritus of the nineteenth-century shopping arcade could be retrospectively interpreted as documents linked to wider cultural and political shifts associated with that period and still influential within his own. The challenge, for Benjamin, was to show how the fragmented rubbish of consumer capitalism was linked to the development of the dreams and nightmares of modernity. Benjamin used allegory in an attempt to show how the remnants of consumption - the discarded adverts and objects - could not be interpreted in their immediacy (that is, simply as adverts and consumables), but always referred back to some further set of codes and forces. The key reference here is Benjamin's Arcades Project (1927-40) and, in particular, his work on Baudelaire (Benjamin 1999: 228-388). Benjamin's above-described critical insight and method can be usefully applied within a reading of Klahr's Altair. That film can be understood to show the reality of post-war American consumer culture. However, this is not because Klahr makes a mimetic, purely reflective documentary examining the period in question. Rather, what Altair provides is a creative re-assembly of a set of codes that allude to the wider framework of post-war American society. Understanding Klahr's film simply as evidence of a nowdead vernacular image culture represents only half the picture. Altair does not just re-present the afterlife of one specific phase in American popular culture: it does something else with that now-discarded imagery. As Klahr has commented: 'What's interesting to me about appropriation is that you are dealing with something that is received, but you are also shaping it in a way that might bring out latent meanings that are not immediately clear' (Chimovitz 1998).

The challenge is to construct a way of linking Klahr's 'shaping' or collaging with animation within Altair to wider cultural and critical notions of 'the document'. In order to develop that project further, productive reference can be made to the work of Siegfried Kracauer, Theodor Adorno, and midtwentieth-century intellectual movements such as Critical Theory and the Frankfurt School. Critical Theory scholars such as Adorno (1994), Benjamin, Max Horkheimer and Kracauer (2012) were notably preoccupied by film and, in particular, by the animated film. As Adorno and Horkheimer (1997: 138) noted,

Cartoons ... accustom the senses to the new tempo, they hammer into every brain the old lesson that continuous friction, the breaking down of all individual resistance, is the condition of life in this society. Donald Duck in the 
cartoons and the unfortunate in real life get their thrashing so that the audience can learn to take their own punishment.

The cartoon form itself - as a product manufactured to entertain participated in the sadomasochistic exploitation of contemporary audiences who were shown how to laugh at their own servitude.

The source of these writers' interest in animation was the manner in which the animated film processed and represented reality in ways that extended beyond the naturalising technology of photography and live-action cinema. The animated image was purposefully - and obviously - constructed. This mediation, while ostensibly disqualifying animated cinema from presenting any neutral and 'pure' access to the external world (which would, obviously, be suspect), actually foregrounded what it meant to imaginatively engage and interact with reality, to the point of effecting an alteration of it. As Gertrud Koch (2000: 106) notes of film - and particularly, animated film - in her book on Kracauer: 'the mediate[d] character of images, insulate[d] [. . . film against the suggestion of directness'. Such a suggestion points to a possibility that interested many of Critical Theory and the Frankfurt School's leading figures: namely, that the animated film had the potential to foreground the constructed nature of human experience. Animated film 'teaches us to see the world' because it allows us to 'see through the false and superficial sensuousness and conventionality of things and perceive behind them the material being of things' (ibid.: 106).

Kracauer, especially in his 1960 book Theory of Film (Kracauer 1997), emphasised this aspect of filmmaking. He suggested that film engages with reality precisely through its constructed material dimension. This was not a pre-given technical capacity of all cinema: rather, it required that a process of visual education and learning to see should occur in the course of making and/or viewing a film. This process implied a physical aspect: an attunement towards movement or, more generally, a somatic, bodily registration during the experience of film viewing. It also implied an awareness that came from the way the viewer saw still or stilled things come alive in film. As a result, Kracauer was very careful to differentiate film from photography. This was because he believed that photography had a tendency to fix and determine the visible world, to create a 'comprehensive catalogue' (Kracauer 1985: 61) of appearances. In an essay on photography, he commented on how: 'The disorder of the detritus reflected in photography cannot be elucidated more clearly than through the suspension of every habitual relationship among the elements of nature' (ibid.: 62). Photography, quite simply, had the power to extract and fix meaning. It was, however, one of film's special qualities to reintroduce movement to the photographically frozen world: 
The capacity to stir up the elements of nature is one of the capacities of film. This possibility is realized whenever film combines parts and segments to create strange constructs. If the disarray of the illustrated newspapers is simply confusion, the game that film plays with the pieces of disjointed nature is reminiscent of dreams in which the fragments of daily life become jumbled. (ibid.: 62)

For Kracauer, film therefore contained the potential for the redemption of things, not just their photographic mortification or reification. Based on the activation of things through the medium of film via movement and time, film had a dialectical relation to reality: the world, the film, and the viewer interacted. This dialectic created momentum, and even drew attention to this process of seeing that it itself provoked. As a consequence, Kracauer proposed, film, rather than mimetically reflecting reality, instead 'look[ed] under the table' (Hansen 1993: 450) of modernity in order to show viewers the process of materialisation - how things do (or do not) enter into meaning within a contemporary world dominated by exchange value. In this way, film had the potential to critically mimic (if not, ultimately, to reverse) the process of commodification. The allusion here to core Marxist concepts should be clear: for Marx, commodification animated objects with a false vitality. Things had a deceitful power over people when the former acquired an exchange value - one aspect of what Marx called, in Capital, the commodity's 'theological capers' (Marx 1982: 163). Commodification created the illusion of activity in inanimate objects. What film could do was to document the effects of this process by shaking the commodified object free - if only for a moment - of the deadening weight of exchange value.

Kracauer's conception of film as a medium could readily be applied within a properly nuanced account of what we see happening in Lewis Klahr's films more specifically. The apparently fixed world of late-1940s Cosmopolitan magazine, laid out according to the order of the magazine's picture editor or the demands of its advertisers, is re-ordered in the collaged Altair. The meaning of the archival magazine imagery that Klahr utilises is found to be more indeterminate than the original capitalistic and consumerist uses to which it was originally put. Klahr re-orders the images and imagery in question so as to create new meanings: what once appeared fixed is latterly revealed to be changeable. One set of possible interpretations (the received idea that a promotional image incontrovertibly tries to sell you something) is superseded when the image in question is suddenly revealed to contain a quite different meaning. In Altair, for example, an advert for a pair of gloves is revealed to be a murderous object that can kill. What Kracauer describes as being generally true of film per se seems true of Klahr's films more specifically. 
Like Kracauer, Adorno also considered that the animated film could have value because of the way it foregrounded the construction of movement from stilled things. The animated film could, therefore, both put on show and mediate our relationship to the dead world of exchange value. Ultimately, however, Adorno's analysis was far more pessimistic than those of many of his critical peers and affiliates. He was much more sceptical of cinema's emancipatory potential than, say, Benjamin, as was evident in their correspondence about the latter's celebrated 1936 essay 'The Work of Art in the Age of Mechanical Reproduction'. Adorno was particularly wary of the way in which he believed animation and cartoons to be complicit in the culture industry. After raising concerns at how 'The laughter of the audience at a cinema . . . is anything but good and revolutionary; instead it is full of the worst bourgeois sadism' (Adorno et al. 2007: 123-4), Adorno goes on to refer to Disney and Mickey Mouse. However, his later analysis of film is interestingly relevant when we return to the issue of animation, the medium's distinctive relationship to concepts of the document, and, in particular, the films of Lewis Klahr.

As Esther Leslie (2002) has shown, the early history of animation appeared to promise (as discerned by Kracauer and others at the time) a form of filmmaking that allowed viewers to see the unruly strangeness of the world. Leslie suggests that watching a cartoon film in the early twentieth century could be liberating experience, because animated films of the period were often chaotic, outrageous and barely controlled cinematic sequences within which the natural laws controlling the outcome of events could not be predicted. With the subsequent industrialisation of animation via companies like Disney, however, the potential for the animated image to show this liberated world - one less confined by the regulation of capitalist society - had (certainly for Adorno, at least) practically evaporated. This would be one way of reading the essays collected in The Culture Industry (Adorno 2001), which can be taken as Adorno's reaction to experiencing American (and, in particular, West Coast American) mass culture in the 1940s. The commonly assumed pessimism of Adorno's critique in essays such as 'The Schema of Mass Culture or Culture Industry Reconsidered' (ibid: 61-106) needs, however, careful consideration. This is because one can find in Adorno's analysis isolated references to the way cinema might still contain traces or fragments of an alternative vision of the world. As a result, the mediums of film and animation still offered a fragile chance to show the utopian potential hidden within the dead commodity that the culture industry offered. In his 1966 essay 'Transparencies on Film' (Adorno 1981), Adorno suggested that one of the ways in which film viewers might escape from industrialised control related to occasions when the cinematic machine broke down or when, through incompetence (deliberate or not), things seemed to go wrong. As he noted: 'works which have 
not completely mastered their technique, conveying as a result something consolingly uncontrolled and accidental, have a liberating quality' (ibid: 199).

When machines or works of art become erratic and unpredictable, the final product or end result is not a foregone conclusion. Depending on what production technique and technology a given artwork employs, the potential type of resulting creative accident is always different. Filmmaking, obviously enough, has created its own (often stereotypical) vocabulary of machine breakdown: the mismatched soundtrack or the burnt-out celluloid strip caught in the projector gate. But what does such a breakdown mean, and how should the viewer interpret this critically?

Referring to Kracauer's Theory of Film, Adorno (1981) discussed how certain types of film and filmmaking possessed the potential to critically examine both their own status as aesthetic objects and the relationship between film, politics and society. This discussion focused in part on a subtle reworking of the terms of Kracauer's ideas about the connection between the technological aspect of cinematic form and that form's intrinsic sociological content. In part, this implied a socio-ontological claim rather like Kracauer's, in the sense that the technology of filmmaking and cinematic representation inferred a link between filmed appearances and the way the world was constructed. Adorno put matters thus: 'by virtue of the relationship to the object, the aesthetics of film is thus inherently concerned with society' (ibid.: 202). If this relationship existed - that is to say, if the form and content of the film interacted with the form and content of society - then through the breakdown of the cinematic machine, or through any creative incompetence employed in a given film's construction, certain social relations could be revealed or analysed. There would be, Adorno's analysis implies, a formal link between the erratic machine that, through malfunction, reveals its inner workings and the social content and context thus revealed. Through those moments of breakdown, viewers would experience or see how erratic capitalism alienates and destroys through the mystifying process of creating abstract exchange value - the stuttering apparatus would reveal the ghost in the machine.

One way of describing this mediating connection would be to focus on how a film or artwork fitted, moulded, adapted, or even defined itself in opposition to historical/social constraints. In Aesthetic Theory, Adorno called this adaptation or fit of the artwork 'aesthetic comportment' (1997: 331). The concept of aesthetic comportment describes the way in which an artwork provokes engagement; it indicates a mediated, sensuous encounter between subject and object that simultaneously jolts the viewer out of their previously petrified state. It also seems, in part, to have some similarities to what Deleuze and Guattari mean by the concept of affect, if we understand affect 
to register a moment of being touched by alterity, a touching that involves both the body and cognition (see Noland 2013). In a suggestive and strange passage, Adorno (1997: 331) proposed that 'aesthetic comportment is to be defined as the capacity to shudder'. Adorno here implies that when we shudder, we are registering an encounter with something that manages to touch us. A shudder indicates an entanglement with something unsettling and strange, and a shuddering, shaking subject is one that is responsive perhaps unwillingly - to others, otherness and difference. As he goes on to note, 'life in the subject is nothing but what shudders' because it 'is the act of being touched by the other' (ibid.: 331). The shuddering self is, therefore, the subject becoming social.

It is in this sense of aesthetic comportment that difference marks the point of social contact via an encounter with alterity. An encounter with others, through the mediation of an aesthetic shudder, shakes us out of our reified selves. It is, says Adorno, as if

Goose bumps were the first aesthetic image. What later came to be called subjectivity, freeing itself from the blind anxiety of the shudder, is at the same time the shudder's own development; the reaction to the total spell that transcends the spell ... that shudder which subjectivity stirs without yet being subjectivity. Aesthetic comportment assimilates itself to that other rather than subordinating it. (ibid.: 331)

The uncertainty induced by unknown difference is, according to Adorno, one of the ways that subjectivity is seen to shudder into being. Social space is the space of uncertainty. ${ }^{2}$ This uncertain, shuddering zone opens up or exposes us to others and other possibilities. When our assumptions or expectations are shaken, we suddenly discover that things - ourselves, other people, society, histories, and ideological apparatuses - could be different. The result of such an encounter is never a foregone conclusion: it is alarming, and even potentially horrifying. Esther Leslie (2009) suggests that this unsettling experience is today most often encountered in a synthetic form, within things like horror films. The latter represent somewhere cinema audiences go for the artificial recreation of Adorno's shudder, a place where viewers can experience themselves being 'undone' by the unknown in order to shake with fear.

With such ideas in mind, the notion of the ghost in the machine takes on a new resonance. Returning to the earlier point about the breakdown of machinery, when a machine shudders we become aware of how unpredictable and fragile it actually is. When the film projector jams, viewers have to acknowledge that the cinematic flow of images is not seamless; when the pixels burn out on a screen, audiences are shaken out of a world of 
seamless appearances. These could all be instances of a cinematic variation of Adorno's shuddering aesthetic comportment.

These links could be applied to Lewis Klahr's work in two ways, in order to see how an Adorno-esque shudder occurs in films such as Altair. Initially, one can see this occurring formally within both this film's narrative and its frame (because, like its alcoholic protagonist, the film itself gets the shakes). Alcohol seems to reduce the female character to a vulnerable state - she seems erratic and discomposed by the narrative's end - and the film mirrors the character's addiction through the mechanics of its animated cut-out imagery. Despite Altair's partial production with digital technology (digital post-production potentially allows the image to be 'perfect', but Klahr deliberately does not use the technology in this way), the finished work shows the cinematic mechanism as still fundamentally unsound and unpredictable. ${ }^{3}$

The second way of linking the thought of Adorno and others to the work of a filmmaker like Klahr concerns a wider formal issue about disruption and disjuncture. It is a familiar observation to suggest that avant-garde works from the early to mid-twentieth century used disruptive shock techniques - Eisenstein's montage, Heartfield's collage, situationist détournement - to create new ways of picturing modernity and shake established sociocultural conventions and meanings. Klahr's films, however, do not use these types of technique simply to disrupt or confront a set of established signifying systems. The films are not directly provocative or challenging in terms of critical interpretation and it is not easy to identify a dialectically deduced meaning, either politically or in terms of general narrative (Pipolo 2013). Rather, Klahr's frames can be described as shuddering in the transition between surface and imagery. The disjuncture in the picture plane, the sense of disconnection between surfaces, and the unsophisticated movements within the frame that one frequently encounters within Klahr's films could all be registered as a disarticulation of a certain aesthetic regime. Klahr's work unsteadies a particular way of thinking and seeing film narrative or durational cinematic flow; his animations question the mechanics of movement and what it means to make a connection. The inability to completely decipher the story in Altair marks, however, a potentially liberating moment - a sense where not knowing what to think is not an uncritical juncture, but a utopian one. We recognise something but we can't definitively say what - and, to that degree, we need to look more. Klahr's films are marked with the potential for the viewer to see a shudder or trembling shadow of critical engagement.

More generally, a nascent contemporary tradition of animated documentary filmmaking can also perhaps be thought of in these terms. What makes the idea of animated documentary relevant here is the way in which it foregrounds the constructed, mediated and social aspects of filmmaking. 
The overarching question, though, remains one of form and content. It might be tempting to suggest that the animated documentary is premised on an encounter with Adorno's critical shudder as a marker of difference: a doubt and uncertainty about our relationship to the world and each other.

\section{CONCLUSION}

In her 2007 essay 'Documentary Uncertainty', the writer and filmmaker Hito Steyerl (2011) questions how documentary film processes and frames viewers' access to the reality of the neoliberal world. Neoliberal capitalism is, in many respects, complicit with the digital world. Chronologically speaking, both phenomena have become increasingly dominant since the late 1960s. Digital technology is also the key tool in establishing and managing the process of globalised financialisation of all aspects of human experience. The contradiction this connection makes apparent is that the intensification and exponential increase in the speed and quantity of images, data and facts that flicker across the different kinds of screens with which we now surround ourselves has not led to a greater understanding of how the world operates indeed, in many respects the opposite has proved true. This process may also have ultimately drained Adorno's shuddering image of any potential. Today, creative flaw has seemingly been reduced to superficially stylised glitch art on Instagram or a commodified aesthetic. Guy Merrill, senior art director at Getty Images, recently stated (2014), for example, that: 'In our increasingly curated world, there's a pull toward an aesthetic that feels messy and unexpected.' Fortunately enough, 'the glitch aesthetic' will, he promises, cater to such desire by bringing 'authenticity to your brand'.

Hence the contemporary crisis of form and content: perhaps there is no way of seeing that is now capable of visualising our lived reality. The absence of any adequate form to represent this crisis registers as a problem for documentation and for the documentary genre in its efforts to show the real. Steyerl (2011) comments on this quandary, noting how: 'the more immediate [documentary pictures] become, the less there is to see'. Remarking on the way in which information, facts, news and 'reality' are now available constantly and inescapably through dematerialised technological images, Steyerl's text focuses on the problem of how the immediacy of this purported reality is actually meaningless. The instantaneous image is both too close and too far away from us, both overt and constant distraction and inescapable background hum. This flow and stream also lacks any filter to aid the processes of grading or deciphering: in other words, this reality's apparent lack of mediation actually leads to a lessening of our access to any reality. 
The result is that any contemporary form that purports to show reality without engaging with the issue of how that reality is being constructed finds itself in danger of becoming what Steyerl might call an 'unmediated documentary'. As an example of this problem, she refers to a case in which a CNN reporter, embedded with a group of American soldiers, documented the latter's arrival in Iraq in 2003. The reporter, using a mobile phone camera, recorded the scene by pointing it out of the window of the vehicle he was travelling in. He then claimed that the footage he relayed showed what was happening in the world in a way never before seen. In one sense, the resulting footage was indeed new; however, due to the constraints of the recording technology, the images were merely a series of abstract blotches and patterns, an inadvertently animated sequence of images and colours that Steyerl called 'abstract documentarism'(ibid.). The attempt to show the real in all its immediacy was too unprocessed: the images meant nothing. To attempt instead to make the documentary figure as a document - to attempt to create comprehensible meaning from the manifold strangeness of the world - requires processes of active intervention and mediation on the artistic practitioner's part. It also requires sensitivity towards the provocation of a critical 'shudder' in film viewers, producers and artworks alike. What make the contemporarily much-discussed question of animated documentary so timely and necessary, then, are the potential ways in which, as this brief examination of Lewis Klahr's work has tried to indicate, that emergent film genre might allow creators and critics to fuse those concerns.

\section{Notes}

1. The literature discussing and analysing the documentary turn is diverse, extensive and not easy to summarise. See, however, books such as The Return of the Real (Foster 1996) for early hints about what is at stake in the reappraisal of documentary forms and later anthologies such as The Green Room: Reconsidering the Documentary and Contemporary Art \#1 (Lind and Steyerl 2008). In relation to recent visual practice, see exhibitions such as Documenta, curated by Okwui Enwezor from 2002, and, in particular, Boris Groys's 2002 essay 'Art in the Age of Biopolitics: From Artwork to Art Documentation' in the catalogue that accompanied Documenta 11; see also the exhibition Experiments with Truth curated by Mark Nash (Nash 2004).

2. A link could be made here to the explanation of chôra - the ambiguous space outside the ordered and controlled world of the city - that Plato mentions in Timeaus. There are, of course, more recent definitions of the term in Derrida or Kristeva, where chôra is used to describe an interstitial zone of encounter (see Marder and Santiago 2014).

3. For more information on Klahr's working methods, see the 2010 Wexner Center for the Arts short film, Studio Visit with Filmmaker Lewis Klabr. 


\section{BIBLIOGRAPHY}

Adorno, Theodor [1966] (1981), 'Transparencies on film', New German Critique, 24/25, pp. 199-205.

Adorno, Theodor [1947] (1994), Composing for the Films, London: Athlone Press.

Adorno, Theodor [1970] (1997), Aesthetic Theory, London: Athlone Press.

Adorno, Theodor (2001), The Culture Industry: Selected Essays on Mass Culture, London: Routledge.

Adorno, Theodor and Max Horkheimer [1944] (1997), Dialectic of Enligbtenment, London: Verso.

Adorno, Theodor, Walter Benjamin, Ernst Bloch, Bertolt Brecht and Georg Lukács (2007), Aesthetics and Politics, London: Verso.

Altair, film, directed by Lewis Klahr. USA: 1994.

Benjamin, Walter (1999), The Arcades Project, Cambridge, MA: Harvard University Press.

Chimovitz, Melissa (1998), 'Declaration of independents: independent animation is alive and well in New York', Animation World Network, 1 May, <http://www.awn.com/animationworld/ declaration-independents-independent-animation-alive-and-well-new-york $>$ (last accessed 24 October 2016).

Foster, Hal (1996), The Return of the Real, Cambridge, MA: MIT Press.

Glynne, Andy (2013), 'Drawn from life: the animated documentary', in Brian Winston (ed.), The Documentary Film Book, Basingstoke: Palgrave Macmillan, pp. 73-6.

Goddard, Peter (2012), 'The Pettifogger, Lewis Klahr's criminal collage', Toronto Star, 5 April, <www.thestar.com/entertainment/2012/04/05/the_pettifogger_lewis_klahrs_criminal_ collage.html> (last accessed 24 October 2016).

Groys, Boris (2002), 'Art in the age of biopolitics: from artwork to art documentation', in Okwui Enwezor (ed.), Documenta 11, Ostfildern-Ruit: Hatje Cantz, pp 108-14.

Hansen, Miriam (1993), “With skin and hair": Kracauer's theory of film, Marseille 1940', Critical Inquiry, 19: 3, pp. 437-69.

Hoberman, James (2000), 'The vulgar classes', Village Voice, 16 May, <http://www.village voice.com/film/the-vulgar-classes-6394814> (last accessed 24 October 2016).

Honess Roe, Annabelle (2013), Animated Documentary, Basingstoke: Palgrave Macmillan.

Koch, Gertrud (2000), Siegfried Kracauer: An Introduction, Princeton, NJ: Princeton University Press.

Kracauer, Siegfried (1985), The Mass Ornament: Weimar Essays, Cambridge, MA: Harvard University Press.

Kracauer, Siegfried [1960] (1997), Theory of Film: The Redemption of Physical Reality, Princeton, NJ: Princeton University Press.

Kracauer, Siegfried [1941] (2012), 'Dumbo', in Siegfried Kracauer's American Writings: Essays on Film and Popular Culture, Berkeley: University of California Press, pp. 139-41.

Leslie, Esther (2002), Hollywood Flatlands: Animation, Critical Theory and the Avant-Garde, London: Verso.

Leslie, Esther (2009), 'Shudder - Shutter - Shatter', animateprojects.org, <http://www.animate projects.org/writing/essay_archive/e_leslie_2> (last accessed 24 October 2016).

Lind, Maria and Hito Steyerl (eds) (2008), The Green Room: Reconsidering the Documentary and Contemporary Art \#1, Berlin: Sternberg Press.

LUX (n.d.), 'Collection/Works/Altair by Lewis Klahr', lux.org, <http://www.lux.org.uk/col lection/works/altair> (last accessed 24 October 2016).

Marder, Michael and Santiago Zabala (eds) (2014), Being Shaken: Ontology and the Event, Basingstoke: Palgrave Macmillan. 
Marx, Karl [1867] (1982), Capital: A Critique of Political Economy, Volume One, Harmondsworth: Penguin.

Merrill, Guy (2014), 'The glitch aesthetic: bringing authenticity to your visual brand', gettyimages. com, 28 August, <http://stories.gettyimages.com/glitch-aesthetic-bring-authenticty-visualbrand $>$ (last accessed 24 October 2016).

Nash, Mark (2004), Experiments with Truth [curated exhibition], Philadelphia: The Fabric Workshop and Museum.

Noland, Carrie (2013), 'Adorno and affect', in James Elkins and Harper Montgomery (eds), Beyond the Aesthetic and the Anti-Aesthetic, Pennsylvania: Penn State University Press, pp. 179-84.

The Pettifogger, film, directed by Lewis Klahr. USA: 2011.

Pipolo, Tony (2013). 'The illustrated man: Tony Pipolo talks with filmmaker Lewis Klahr', Artforum, March, pp. 243-9.

Redcat (2006), 'Re-animation: an evening with Lewis Klahr', 16 October, <http://www. redcat.org/event/re-animation-evening-lewis-klahr> (last accessed 24 October 2016).

Steyerl, Hito [2007] (2011), 'Documentary uncertainty', Re-visiones, 1, <http://www.re-vis iones.net/spip.php\%3Farticle37.html $>$ (last accessed 24 October 2016).

Studio Visit with Filmmaker Lewis Klahr, film, directed by Anon. USA: Wexner Center for the Arts 2010, <http://wexarts.org/blog/video-studio-visit-lewis-klahr> (last accessed 24 October 2016). 